\title{
The Predicament and Countermeasures of English Writing in Senior High School Teaching
}

\author{
Yanrong $\mathrm{Li}^{1}$ \\ ${ }^{1}$ Gannan Normal University, Ganzhou, China \\ Correspondence: Yanrong Li, Gannan Normal University, Ganzhou, Jiangxi, China. E-mail: \\ 1872206016@qq.com
}

Received: January 20, 2022

Accepted: February 18, 2022

Online Published: February 27, 2022

doi:10.20849/aes.v7i1.1016

URL: https://doi.org/10.20849/aes.v7i1.1016

\begin{abstract}
As an important part of high school English classroom teaching, writing teaching is one of the important ways to improve students' English learning ability. As for the current high school English writing teaching, there are still many problems in classroom learning. For example, the students' writing efficiency is not high, the number of words in the classroom writing practice is not enough, off-topic, and writing interest is not high are the practical problems that high school teachers need to solve urgently.
\end{abstract}

Keywords: senior high school English, writing teaching, predicament, countermeasures

The traditional writing teaching mode is monolithic, the interaction between teachers and students is formalized, and the teaching quality is not high. These factors directly restrict the comprehensive development of high school students' comprehensive ability, and also make their writing level improvement and creative thinking activities. Under the background of the new curriculum reform, teachers should re-construct the writing teaching mode. By optimizing the teaching process, changing students' learning attitudes, guiding students' incorrect writing methods, and aiming at stimulating students' enthusiasm, allowing students to devote themselves to writing exercises and challenging themselves, students will have a chance to become a rare talent.

\section{Problems Existing in the Teaching of English Writing in Senior High School}

One of the main problems in English writing teaching in senior high schools is that the teaching methods are too single. Faced with the pressure of college entrance examination, some teachers blindly emphasize teaching efficiency and always ask students to carry out repeated training in the teaching process.

Generally, the teacher gives a composition proposition, and then asks the students to write, and asks the students to use the recently learned words or grammar knowledge in writing. Such writing not only has a single teaching method, but also has a narrow range of writing topics, ignoring students' interests and actual life experience. This teaching method is not conducive to improving students' writing ability. This practice damages students' interest in English writing and makes students feel that writing is not to meet their own needs for expression, but a simple learning task. They don't do it for themselves, but write for teachers and exams. In this case, students will naturally not consider how to express their ideas clearly and think about English writing skills, as long as there are no mistakes in basic knowledge, they will feel that the task is completed.

\section{Strategies to Improve the English Writing Ability of High School Students}

\subsection{Strengthen the Learning of Textbooks and Infiltrate the Teaching of Writing}

English teaching in high school is mainly based on teaching materials, so teachers must make full use of teaching materials. In the writing class, students must first complete the relevant writing exercises in class, and then develop their extracurricular writing on this basis. Therefore, in the teaching activities, teachers can infiltrate the articles and dialogues in class into the writing teaching, so that in the writing class, students will have a sense of familiarity with the knowledge they have learned in the past, thereby reducing the psychological impact of English writing difficulty, which is conducive to students' better writing activities. 


\subsection{Develop Teaching Strategies Based on Students'Abilities}

The formulation of teaching strategies is based on the learning level of students. For students with a higher level of learning, what they need is to practice personalized writing; for students with an intermediate level, they should ensure a steady improvement on the original basis; for students with learning difficulties, they need to first make up for obvious defects and consolidate the foundation of English writing. There should be different writing teaching strategies among the three. Therefore, teachers should fully understand the level of students through classroom observation and in-class evaluation and then formulate teaching strategies. They should not rush for success and always give students exactly the same learning tasks.

\subsection{Pay Attention to the Writing Process and Master the Format}

High school English teachers should pay enough attention to the writing process of high school English, and should not ignore the teaching quality to catch up with the progress. Teachers should open students' writing ideas, properly solve students' writing "sameness" problem, do not limit their thinking development, teachers should guide students in bold ideas, review the topics, let students have full thinking of writing, good at filling more content, from a single format and clear writing specification, so that the students have their article readable. Students get different cognitive experience in-classroom training, so there is naturally more room for improvement in academic performance. For example, use the common "letter" format: "How nice to hear from you. again." "First of all, please allow me to represent all of you here." Students take these forms and try to introduce more complex advanced vocabulary to the article to improve the quality of writing. In addition, teachers should also exercise the students' use of vocabulary and inspire students: "I hope you will think carefully about whether the use of English vocabulary is appropriate and make your article more logical." Under the deliberate guidance of the teacher, students will slowly check the content of the article carefully to form a habit of writing practice and active reflection, which is of great benefit to the comprehensive development of senior high school students' writing ability.

\subsection{Use Imitation Teaching Method to Improve Writing Ability}

To improve students' interest in writing and the effectiveness of training, teachers can first guide students to imitate English. Since English is not the students' native language, students are required to imitate training around cases, which should not be imagined. For high school students, imitation learning is not difficult, so students can start by imitating technical structures and gradually master the methods and routines of writing sentences. After the students have mastered the method of imitating simple sentences, they can allow them to imitate complex sentences. In the process of writing, more practice, more reading, more study, and more writing can build an English learning scene for students. For example, attributive clauses, noun clauses, inverted sentences, etc. are often used in the composition. Through the imitation of these sentence structures, students can add luster to their compositions and improve the quality of their compositions. Proper application can help students get higher scores in college entrance exam essays. Through imitation, students can also know what kind of composition is a good composition, and how to make a good composition layout. Only by letting students know what kind of content is good can they write good content.

\section{Conclusion}

To sum up, there are still some problems in English writing in high school. The main reason is that the educational concepts of some English teachers have not been updated, but only the details of teaching methods have been adjusted and the impact on the improvement of teaching quality is relatively limited. If the problem of students' interest in learning is not solved, it will be difficult to obtain substantial progress in teaching effect. For this reason, the majority of teachers should adjust the teaching theory in time, then set up teaching strategies and teaching methods on this basis, and insist on taking the situation and needs of students as the most important teaching basis, and finally will be able to obtain better and better teaching results.

\section{References}

Su, T.-Y. (2020). Current Situation and Improvement Countermeasures of English Writing. Teaching in Senior High School Students' English, (38), 14-15.

Wang, M. (2021). The Dilemma and Countermeasures of English Writing Teaching in Senior High Schools. 
Men's Enlightenment and Wisdom (middle), (2), 26.

Yang, L. (2020). High School Students 10011 English Writing Dilemma Cause Analysis and Countermeasures. Research Door-New Course, (52), 62.

\section{Copyrights}

Copyright for this article is retained by the author(s), with first publication rights granted to the journal.

This is an open-access article distributed under the terms and conditions of the Creative Commons Attribution license (http://creativecommons.org/licenses/by/4.0/). 